\title{
Examining the Antecedents of Environmentally Responsible Behaviour: Relationships among Service Quality, Place Attachment and Environmentally Responsible Behaviour
}

\author{
Tian E Cheng ${ }^{1}$, Shasha $\mathrm{Li}^{1}$, Heng Zhang ${ }^{1}$ and Mingming Cao ${ }^{2, *}$ \\ 1 School of Foreign Languages, Northwest University, Xi'an 710069, China; cte201707@nwu.edu.cn (T.E.C.); \\ qli71846@gmail.com (S.L.); 202132648@stumail.nwu.edu.cn (H.Z.) \\ 2 School of Human Settlements and Environment, Xi'an Eurasia University, Xi'an 710065, China \\ * Correspondence: chengshi@nwu.edu.cn
}

check for updates

Citation: Cheng, T.E.; Li, S.; Zhang, H.; Cao, M. Examining the Antecedents of Environmentally Responsible Behaviour: Relationships among Service Quality, Place Attachment and Environmentally Responsible Behaviour. Sustainability 2021, 13, 10297. https://doi.org/ $10.3390 /$ su131810297

Academic Editor: Jorge Matute

Received: 19 August 2021

Accepted: 13 September 2021

Published: 15 September 2021

Publisher's Note: MDPI stays neutral with regard to jurisdictional claims in published maps and institutional affiliations.

Copyright: (c) 2021 by the authors. Licensee MDPI, Basel, Switzerland. This article is an open access article distributed under the terms and conditions of the Creative Commons Attribution (CC BY) license (https:/ / creativecommons.org/licenses/by/ $4.0 /)$.

\begin{abstract}
This study investigates the antecedents of environmentally responsible behaviour by creating a theoretical model of relationships between service quality, place attachment and environmentally responsible behaviour. A questionnaire survey was conducted among tourists who visited six famous tourist attractions in Shaanxi, China. The results of the research demonstrate that service quality exerts influence on environmentally responsible behaviour and place attachment in a positive manner. Additionally, the findings suggest that place attachment affects environmentally responsible behaviour in a direct and positive manner. Moreover, it is also found that service quality strengthens its effect on environmentally responsible behaviour through place attachment, indicating the mediating role of place attachment in the link between service quality and environmentally responsible behaviour. The current research contributes to tourism literature in that it helps to better understand the tourists' environmentally responsible behaviour and provides management with evidence of the significance for improving the service quality at tourist attractions.
\end{abstract}

Keywords: service quality; place attachment; environmentally responsible behaviour; tourist attractions; Shaanxi

\section{Introduction}

In recent years, the tourism industry in Shaanxi has been developing rapidly, with a steady growth in the total number of tourists and total income from tourism. In 2017, tourists made 522.8 million visits to tourist attractions in the province, an increase of $16.41 \%$ compared with those in 2016, and the total income from tourism was CNY 481.3 billion (USD 74.5 billion), an increase of $26.23 \%$ compared with that in 2016. In 2017, tourists made 46.7 million visits to the six most famous tourist attractions (the study sites chosen for the present study) in Shaanxi, which brought a total tourist income of CNY 2.1 billion (USD 0.32 billion) (data source: Shaanxi Tourism Statistics Fact sheet, 2018).

While the growing number of visitors brings considerable income, they also contribute considerably to the negative impact upon and damage to tourist resources, as well as to the environment of the visited sites. The tourists' inappropriate behaviour, such as littering, scribbling on cultural relics, picking flowers, climbing trees, trampling on vegetation, disturbing wildlife habitats, feeding animals, etc., will directly or indirectly affect or even destroy the physical environment of the tourist attractions, which puts tremendous pressure on the sustainable use of tourist resources and sustainable development of local tourism. If tourists voluntarily adopt environmentally responsible behaviour, the sustainable use of tourism resources will be promoted. Some scholars maintain that encouraging visitors to exhibit environmentally responsible behaviour is the most important means to reduce negative or even destructive effects on the tourist environment [1]. They hold that appropriate behaviour is beneficial to the sustainable use of tourist resources and 
ultimately promotes the sustainable development of tourism [2,3]. Cultivating environmentally responsible behaviour among visitors seems to be the best management strategy to achieve the above objectives. However, what factors might influence the tourists' environmentally responsible behaviour? As far as the tourists themselves are concerned, what might promote them to exhibit environmentally responsible behaviour?

Goffman (1963) held that an individual's attachment to a place provided a different perspective for studies of human behaviour. Place attachment is viewed by scholars in tourism research as one's attachment to the physical place and the symbolic meanings related to the place $[4,5]$. Past research has suggested that tourists' attachment to a place affects their behavioural intentions such as the mode of involvement in leisure and recreation activities [6], behavioural loyalty $[7,8]$, etc. What is more, attached tourists were found to be more environmentally conscious and more willing to adopt environmentally responsible behaviour $[9,10]$. Many studies have found that tourists' place attachment significantly influenced their environmentally responsible behaviour [11,12]. Therefore, place attachment is viewed as one of the certain antecedents that predicts environmentally responsible behaviour by a majority of researchers $[10,13,14]$. What should be pointed out is that the existing studies have been mainly conducted on nature-based sites which receive an appropriate number of tourists. Will tourist attachment to a cultural heritage site or nature-based site which receives far too many tourists also affect their environmentally responsible behaviour? This is a meaningful research topic worthy of exploration.

Since tourism is a subsection of the service industry, is it possible for the service quality at the tourist attraction to affect tourists' environmentally responsible behaviour? Researchers in the marketing field have studied the influence of service quality on consumers' various behavioural intentions such as purchase [15], loyalty [16], repurchase, and word-of-mouth $[17,18]$, etc, and the majority of the research results have suggested that the service quality has a positive effect on the above behavioural intentions. In leisure and tourism research, scholars chose different study settings such as recreation resorts, tourist destinations, etc., to explore the influence of service quality on tourists' behavioural intentions and the research has found that service quality affects the tourists' intention to revisit [19-21], destination loyalty [22], word of mouth [23]. According to the above literature, the service quality at tourist attractions very likely affects tourists' environmentally responsible behaviour. Therefore, this study attempts to investigate the effect of service quality on environmentally responsible behaviour.

In addition to influencing tourists' behavioural intentions, is it possible for service quality to affect the tourists' place attachment? Research in marketing literature has shown that emotional attachment influences the way consumers evaluate service quality and that of decision-making behaviour results [24]. In tourism literature, with the exception of the four studies [25-28], service quality has not been investigated in relation to place attachment. Despite rather scant research, different or even contradictory results have been found. The results of past research indicates that the link between service quality and place attachment has not been well established, hence the need for further exploration. The present study attempts to investigate whether the service quality at tourist attractions affects place attachment. To better understand the variables influencing environmentally responsible behaviour, the present study also attempts to investigate whether service quality strengthened its effect on environmentally responsible behaviour through place attachment, namely, to test the mediating role of place attachment.

To explore the answers to several of the abovementioned questions, the current study aims to achieve the following objectives: (1) to create a theoretical model to evaluate the effect of service quality on place attachment and environmentally responsible behaviour; (2) to present research results of the relationships between service quality and place attachment; (3) to provide tourist management with suggestions for improving the service quality at tourist attractions.

Our research contributes to tourism literature in that this is the first attempt to investigate the effect of service quality on the tourists' environmentally responsible behaviour in 
scenic spots, including both cultural heritage sites and nature-based sites. What is more, it is among the first to access service quality at the most famous six tourist attractions in Shaanxi and explore its influence on the tourists' place attachment and environmentally responsible behaviour, which suggests the significance of service quality management for the sustainable use of tourism resources and the sustainable development of local tourism.

\section{Literature Review and Model Development}

\subsection{Service Quality and Environmentally Responsible Behaviour}

Literature from different fields has shown that service quality affects behavioral intention and past research indicates that service quality can predict and interpret consumers' behavioural intention. Chiou and Droge ascertained that service quality is a cognitive factor that precedes any emotional response and ultimately stirs behavioural intention (i.e., cognition-emotion-behaviour) [29]. In tourism literature, current research is revealing that service quality might influence future behavioural intention, such as the intention to revisit and word of mouth recommendation [30]. Some scholars believe that service quality perception influences behavioural intention, which should be especially valued by those who manage tourist destinations [31,32]. Lee et al. have examined the outcomes of service quality perceptions on satisfaction, revisiting intention and gender role by using golf club businesses as a study context. Their findings demonstrate that two critical aspects of service quality (tangibility and empathy) determine the satisfaction of golfers [19]. Wang et al. in their study have integrated several extant scholarly models to investigate the relationship between the perception of destination quality, satisfaction, visit frequency and word of mouth recommendation. The results indicate that destination quality perception has a direct and positive effect on word of mouth recommendation [23].

Kim et al. have used data collected from visitors who attend the Seoul Lantern Festival in South Korea to explore the relationship between festival quality, behavioural intention and place attachment. The findings of the study reveal that festival quality directly and significantly influences behavioural intentions in the form of repeat visits, spreading word of mouth and engaging in environmentally responsible behaviour. Additionally, the results show that place attachment plays a mediating role between festival quality and behavioural intentions [24]. Based on the past empirical studies of the possible effect of service quality on behavioural intentions, we posit that the service quality of tourist attractions potentially affects tourists' environmentally responsible behaviour and the following hypothesis is proposed:

Hypothesis 1 (H1). Service quality has a positive effect on environmentally responsible behaviour.

\subsection{Service Quality and Place Attachment}

To our best knowledge, only four studies in the tourism literature have investigated the influence of service quality on place attachment. Lee has examined the antecedents of destination loyalty in a forest setting by creating a model to explore the relationship between service quality, satisfaction, activity involvement and place attachment in predicting destination loyalty. The findings reveal that service quality impacts place attachment in a positive manner, indicating that forest recreationists who perceive a high service quality tend to develop an emotional attachment to the visited forest. Additionally, service quality strengthens its influence on place attachment through the mediator of activity involvement. The study results also show that place attachment and satisfaction mediates the link between service quality and behavioural loyalties [25]. Alexandris et al. have investigated the contribution of place attachment and service quality in increasing customers' behavioural loyalty in a skiing resort. The results indicate service quality significantly predicts place attachment and place attachment significantly predicts skiers' loyalty [26].

Hwang et al. have examined the variables influencing an interpretation service by using Taiwan parks as study areas. The findings demonstrate that place attachment and tourists' involvement is positively associated with the interpretation service quality. In 
addition, an indirect and positive effect from place attachment to the interpretation service exists [27]. Morgan has conducted a study to investigate whether an interpretation service contributes to the development of place attachment. However, the results showed that the place attachment scores were similar before and after the tour, indicating interpretation fails to influence place attachment [28].

To date, very few studies have explored the link between service quality and place attachment, despite inconsistent or even contradictory results. Lee and Alexandris et al. suggest that service quality influences the development of place attachment. However, Hwang et al. have found that place attachment influences interpretation service quality, which conflicts with Lee and Alexandris et al.'s study results. Morgan in his study found that the interpretation service did not influence place attachment.

In spite of inconsistent study results, these four studies are quite valuable in that they have discovered a research topic that needs much further exploration which will arouse other researchers' interest. The authors of this study attempt to posit that service quality might affect the development of tourists' place attachment based on the nature of the place attachment construct. It is widely accepted that the construct of place attachment consists of two dimensions: place dependence and place identity. Place dependence emphasizes functional attachment to a place because the place can provide the necessary resources or facilities to meet the individual's specific activity needs [33] and place identity reflects the symbolic importance of a place to a person [4]. Therefore, very probably, when the management of tourist attraction provides satisfying service, the tourist might develop attachment to the tourist attraction. Thus we propose the following hypothesis:

Hypothesis 2 (H2). Service quality has a positive effect on place attachment.

\subsection{Place Attachment and Environmentally Responsible Behaviour}

Some studies in the literature of leisure and recreation as well as tourism show that place attachment plays a significant role in explaining an individual's behavioural intentions [27]. In the field of tourism, it has been found that place attachment is a positive predictor of environmentally responsible behaviour [3,13]. According to the findings of previous studies, when tourists are highly attached to tourist attractions, they are more likely to adopt environmentally responsible behaviour [14,34]. Cheng et al. have examined the impact of place attachment on destination attractiveness and environmentally responsible behaviour. The results show that place attachment is positively associated with stronger environmentally responsible behaviour. Ramkissoon et al. have employed data collected from tourists who visit a National Park in Australia to examine the effect of place attachment on environmentally friendly behaviour. The findings indicate that the dimension of local attachment significantly affects low-effort environmental protection behaviour and high-effort environmental protection behaviour. Tonge et al. have the view that if individuals develop emotional attachment to a place, very probably they will tend to protect the place. They have examined the influence of place attachment on environmentally responsible behaviour by collecting data from visitors to Ningaloo Marine Park, Australia. The results reveal that place identity affects behavioural intentions in a direct and significant manner. Although previous studies suggest consistent results, namely place attachment can be used to predict environmentally responsible behaviour, yet these studies have been conducted in nature-based sites such as national parks, wetlands various resorts, etc. Using both cultural heritage sites and nature-based sites as study areas, this study proposes that the place attachment of tourists who visit either cultural heritage sites or nature-based affects their environmentally responsible behaviour. Therefore, this study puts forward the following hypothesis:

Hypothesis 3 (H3). Place attachment has a positive effect on environmentally responsible behaviour.

Researchers from the field of social and environmental psychology have explored the impact of place attachment on environmentally responsible behaviour and the findings 
indicate that place attachment can interpret the visitors' environmentally responsible behaviour in various contexts [11,12]. Some research in tourism literature has also found that place attachment plays an important role in predicting the tourists' environmentally responsible behaviours [35]. In linking this evidence for the impact of place attachment on environmentally responsible behaviour with hypothesis 3 of "Place attachment has a positive effect on environmentally responsible behaviour", the mediating role of place attachment on service quality and environmentally responsible behaviour linkage might logically be expected. Namely, service quality can strengthen its effect on environmentally responsible behaviour through place attachment. Therefore, this study predicts the mediating role of place attachment in the relationship between service quality and environmentally responsible behaviour.

The proposed hypothesis is as follows:

Hypothesis 4 (H4). Place attachment mediates the effect of service quality on environmentally responsible behaviour.

Based on the above analysis of previous studies concerning service quality, place attachment and environmentally responsible behaviour and the four proposed hypotheses, the theoretical model representing the relationships between the three variables is as follows (Figure 1):

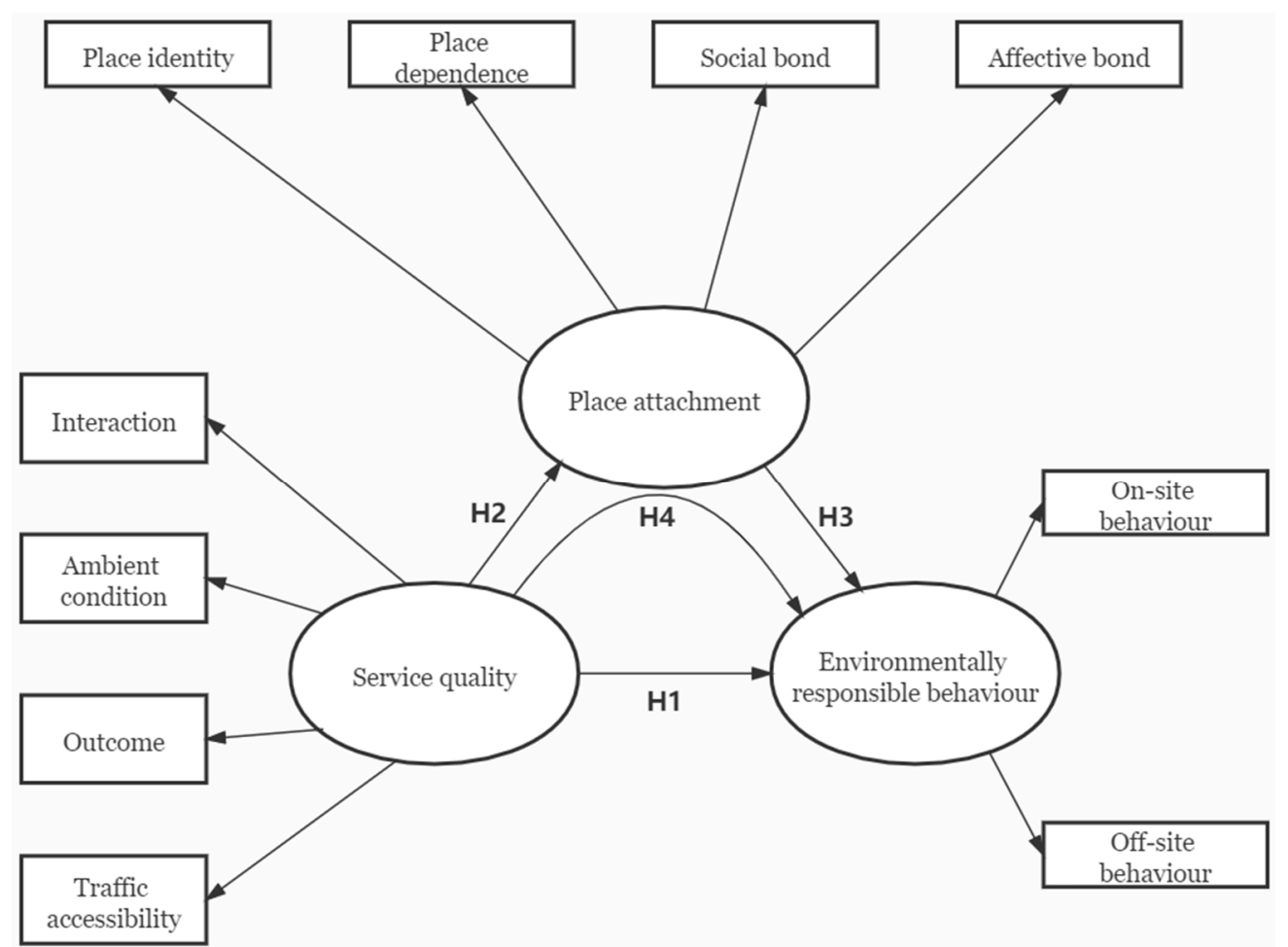

Figure 1. Hypothesised relationships between service quality, place attachment and environmentally responsible behaviour.

\section{Methodology}

\subsection{Study Area}

The study selected six famous tourist attractions in Shaanxi, China as study sites: Emperor Qin Shihuang's Mausoleum Site Museum is a large site museum which is listed as the Eighth Wonder of the World; Huaqing Palace is characteristic of the Tang culture (618-907A.D.) and famous for its hot springs and imperial palaces; the Dayan Pagoda and Tang Paradise are two neighboring historic sites and the former is famous for being a repository of Buddhist scriptures while the latter features the Tang culture; the Mausoleum 
of the Yellow Emperor is a shrine to worship the progenitor of the Chinese people-also known as the Emperor Xuanyuan and it is hailed as the No. 1 Mausoleum in China; the Famen Temple is a holy site for Buddhism since Sakyamuni's finger bone is kept there as a relic; Mount Hua, one of the five famous mountains in China, is known for its five peaks which are precipitous and dangerous (Figure 2).

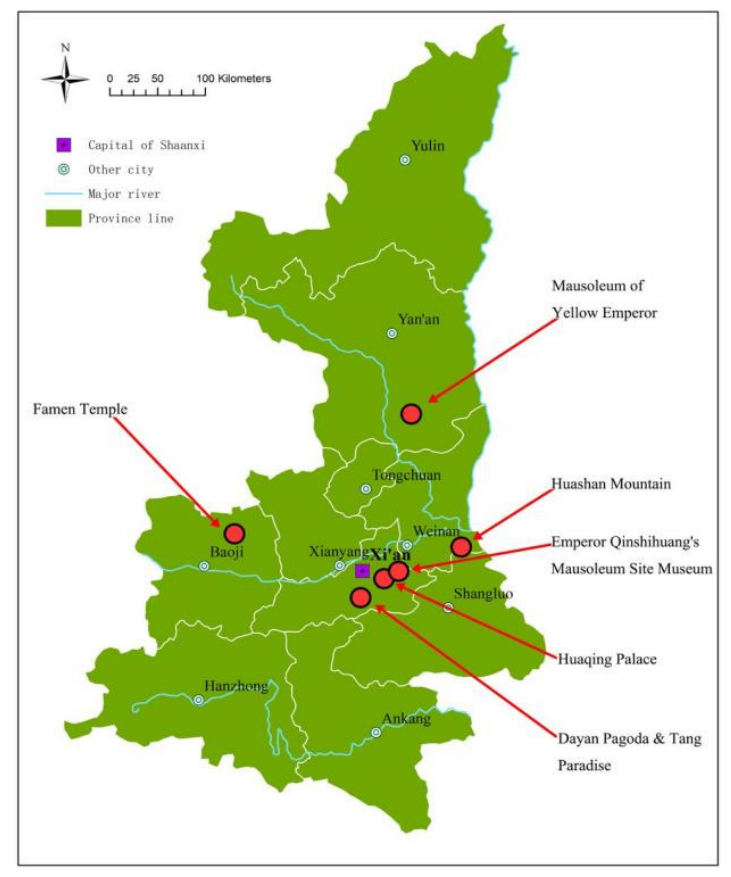

Figure 2. Study area.

\subsection{Measurement of Constructs}

This study combines the research results of the two schools from northern Europe and the United States to establish the measuring construct of service quality, which consists of four dimensions, namely employer-customer interaction, ambient quality, outcome and traffic accessibility. Thirty-two indicators have been identified so as to evaluate the visitors' perception of service quality. Place attachment is measured from 4 dimensions, that is, place dependence, place identity, social bond and affective bond. The corresponding items are borrowed from Williams and Vaske's study [4] and 17 items are designed to measure the four aspects of place attachment. Referring to the study results of Smith-Sebasto and D' Costa [36], the researchers have devised 9 items to measure environmentally responsible behaviour. A 7-point Likert scale was employed to score all the statements, on which "7" stood for "completely agree" and " 1 " meant "completely disagree". The higher the visitor's evaluation score for each indicator, the greater their satisfaction was judged to be. A lower score, meanwhile, showed less satisfaction with the evaluated indicator.

\subsection{Questionnaire Design and Data Collection}

The questionnaire comprise two parts. Part one included 58 indicators measuring service quality, place attachment as well as environmentally responsible behaviour. The second part was the demographic features of respondents. A pretest of 230 questionnaire surveys was taken. Based on the analysis of reliability and validity, 3 statements were deleted and the rest were retained. Among the three deleted items, 2 were devised for measuring place attachment and 1 for environmentally responsible behaviour. As a result, 55 indicators were used to measure the three variables (see Appendix A).

The number of questionnaires distributed at each study site was based on the total number of visitors in the previous year of 2017. In 2017, the total number of visitors to the selected 6 tourist attractions was 46,726,600, among which the Emperor Qin Shihuang's Mausoleum Site Museum accounted for 15\% $(6,850,000)$, Huaqing Palace accounted for 
9\% $(4,210,000)$, the Dayan Pagoda and Tang Paradise accounted for $64 \%(29,869,000)$, the Mausoleum of the Yellow Emperor was about $3 \%(1,347,600)$, Famen Temple was around $3 \%(1,420,000)$ and Mount Hua was about $6 \%(2,630,000)$. To ensure that valid samples for each site were not below the minimum samples of 30 , the total minimum samples for 6 sites were calculated: $30 / 3 \%$ (the percentage of the smallest visitor numbers) $=1000$. The researchers then calculated the minimum number of valid samples for each site according to their corresponding percentage of the total number of the 6 sites. To make sure that the collected valid samples exceeded the minimum number of samples, more questionnaires were distributed at each site.

The trained research assistants went to the exits of the above mentioned six tourist attractions to distribute questionnaires. Convenience sampling was used to conduct the survey and the tourists aged 18 and above who finished their tour were chosen as the potential subjects. Each respondent was given a small gift to show our appreciation for their cooperation. Self-administrated questionnaires were distributed and answered on site. The survey lasted from May to October 2018.

Four research assistants went to conduct questionnaire survey at the exit of Emperor Qin Shihuang's Mausoleum Site Museum. It took the team members 3 days (from 1 to 3 May 2018) to distribute 300 questionnaires and 247 ones were useable, with a valid returned rate of $82 \%$. It took four group members two days (23-24 June 2018) to distribute 200 questionnaires at the exit of Huaqing Palace and 164 useable ones were obtained, with a valid return rate of $82 \%$. Six research team members spent 5 days (27-31 July) distributing 800 questionnaires at the exit of the Dayan Pagoda and Tang Paradise and 664 useable ones were collected, with an effective rate of $83 \%$. Four group members spent 2 days (14-15 July) distributing 200 questionnaires at Mausoleum of Yellow Emperor and 172 valid questionnaires were collected, with a valid return rate of $86 \%$. Two hundred questionnaires were distributed at the exit of the Famen Temple (23-24 September) and 159 valid questionnaires were collected, with an efficiency of $79 \%$. A further 200 questionnaires were distributed in Mount Hua and 156 valid questionnaires were collected, with a valid return rate of $78 \%$. A total of 1900 questionnaires were distributed at the six scenic spots and 1562 valid ones were collected, with a valid return rate of $82 \%$ (Table 1 ).

Table 1. Survey samples.

\begin{tabular}{|c|c|c|c|c|c|c|}
\hline Tourist Attractions & $\begin{array}{l}\text { Visitor Number in } \\
2017(\%)\end{array}$ & $\begin{array}{l}\text { Minimum } \\
\text { Sample (\%) }\end{array}$ & $\begin{array}{l}\text { Total } \\
\text { Surveys }\end{array}$ & $\begin{array}{l}\text { Returned } \\
\text { Surveys }\end{array}$ & $\begin{array}{l}\text { Valid Sample } \\
\qquad(\%)\end{array}$ & Survey Time \\
\hline $\begin{array}{l}\text { 1. The Emperor Qin Shihuang's } \\
\text { Mausoleum Site Museum }\end{array}$ & $6,850,000(15 \%)$ & $150(15 \%)$ & 300 & 247 & $82 \%$ & 1 May 2018 \\
\hline 2. Huaqing Palace & $4,210,000(9 \%)$ & $90(9 \%)$ & 200 & 164 & $82 \%$ & 23 June 2018 \\
\hline 3. Dayan Pagoda and Tang Paradise & $29,869,000(64 \%)$ & $640(64 \%)$ & 800 & 664 & $83 \%$ & 27 July 2018 \\
\hline 4. Mausoleum of the Yellow Emperor & $1,347,600(3 \%)$ & $30(3 \%)$ & 200 & 172 & $86 \%$ & 14 July 2018 \\
\hline 5. Famen Temple & $1,420,000(3 \%)$ & $30(3 \%)$ & 200 & 159 & $79 \%$ & 23 September 2018 \\
\hline 6. Mount Hua & $2,630,000(6 \%)$ & $60(6 \%)$ & 200 & 156 & $78 \%$ & 3 October 2018 \\
\hline Total & $46,726,600$ & 1000 & 1900 & 1562 & $82 \%$ & \\
\hline
\end{tabular}

\section{Results of the Study}

\subsection{Demographic Profile of the Respondents}

According to the collected data, the proportion of female visitors (63.6\%) was greater than that of male visitors (36.4\%). A majority of them were young people and $28.7 \%$ of the respondents were within the 25-34 age bracket. Married respondents accounted for $34 \%$. Of them, $66.9 \%$ and $42.4 \%$ had received a college education. Most of them $(80.4 \%)$ travelled alone and $43.3 \%$ travelled with friends. Some $58.1 \%$ of the subjects came from other provinces while $38 \%$ were from Shaanxi province. Most of the respondents $(77.2 \%)$ were visiting the attractions for the first time. It took most of them (64.2\%) 3-4 hours to visit the attraction. The visiting purpose of $61.7 \%$ was to learn about history as well as the cultures of the visited sites, $57.1 \%$ for relaxation, and $52.9 \%$ visited the place on account of the high reputation of the site (Figure 3 ). 


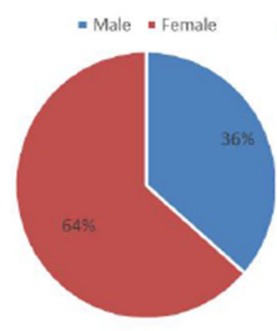

Gender

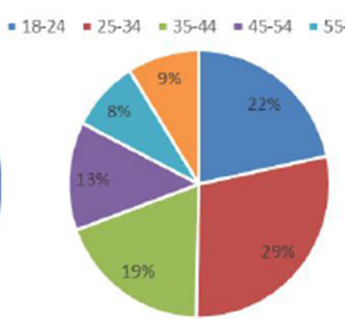

Age

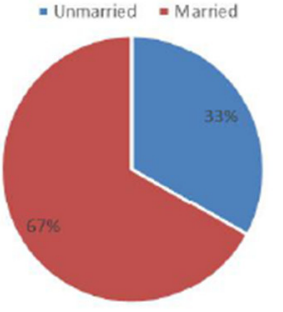

Marital status

- Junior high school \& below a Senior high school

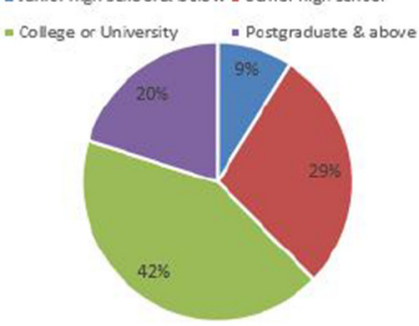

Education

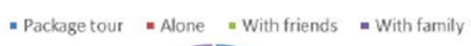

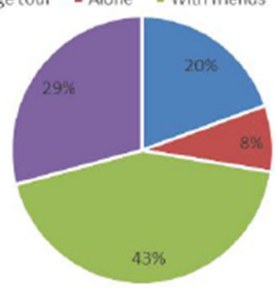

Companions

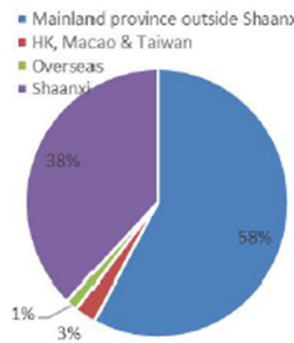

Residence of visitors

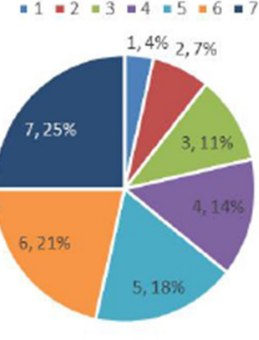

Visiting experience

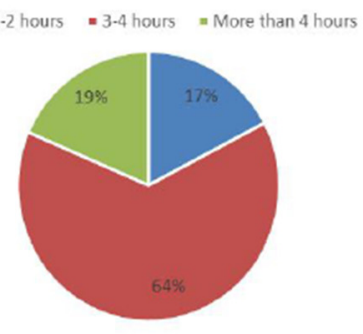

Visiting hours

Figure 3. Demographic profile of the subjects.

\subsection{Data Analysis of Service Quality Scale}

The reliability and validity of the service quality scale was tested by utilizing SPSS 24.0 to discover whether the instrument had good internal consistency. Test results showed that the value of Cronbach's alpha (within the range of 0.864 and 0.944 ) was higher than 0.7, which showed that the internal consistency of the service quality scale was good. Further exploratory analysis was made by using principal component analysis and varimax rotation for factor analysis and convergent factor extraction. Factor loadings (within the range of 0.610 and 0.802 ) of service quality items were significant. Composite reliability (CR) (within the range from 0.864 to 0.945 ) exceeded 0.60 , indicating a good reliability of service quality scale (Table 2).

Confirmatory factor analysis was employed to determine the fitting ability of the constructed factor model to the actual data. The test results showed that all of the indices were satisfactory: the CMIN/DF was 2.681, lower than 3, indicating model's goodness-offit was acceptable. Other goodness-of-fit statistics like GFI (0.952), NFI (0.964), AGFI (0.945), TLI (0.975), CFI (0.977), IFI (0.977) were all above the threshold value of 0.9 and RMSEA was 0.033 , below 0.08 , which indicated that the model fitness can be accepted (Table 3). 
Table 2. Cronbach's alpha, factor loadings, CR and AVE of service quality scale.

\begin{tabular}{|c|c|c|c|c|}
\hline Measured Variables and Dimensions & Cronbach's Alpha & Factor Loadings & CR & AVE \\
\hline Employee-customer interaction & 0.906 & & 0.908 & 0.622 \\
\hline The staff here are friendly and well-mannered. & & 0.750 & & \\
\hline The staff here serve visitors actively. & & 0.790 & & \\
\hline The staff are experienced in solving visitors' problems. & & 0.768 & & \\
\hline Tour guides have considerable expertise in this tourist attraction. & & 0.756 & & \\
\hline Tour guides are competent in their job. & & 0.799 & & \\
\hline Tour guides can give timely and accurate answers to visitors' questions. & & 0.748 & & \\
\hline Ambient condition & 0.944 & & 0.945 & 0.656 \\
\hline This place is peaceful and attractive. & & 0.740 & & \\
\hline The climate here is comfortable and pleasant. & & 0.754 & & \\
\hline It is safe to tour this place. & & 0.703 & & \\
\hline Tour routes are well designed. & & 0.760 & & \\
\hline $\begin{array}{c}\text { The style and colour of the buildings and other facilities on the site } \\
\text { match the surroundings. }\end{array}$ & & 0.802 & & \\
\hline The layout of the facilities is reasonable. & & 0.753 & & \\
\hline Visitors here are polite and well mannered. & & 0.756 & & \\
\hline The number of visitors influences service quality of the site. & & 0.751 & & \\
\hline $\begin{array}{l}\text { The management of this place is aware that number of visitors } \\
\text { influences service quality. }\end{array}$ & & 0.674 & & \\
\hline Outcome & 0.938 & & 0.938 & 0.540 \\
\hline The staff serve tourists promptly. & & 0.675 & & \\
\hline The management tries to reduce visitors' waiting time for service. & & 0.691 & & \\
\hline Waiting time in this place can be predicted. & & 0.683 & & \\
\hline Sufficient quality recreational facilities are provided for visitors. & & 0.673 & & \\
\hline Restaurants here are sanitary. & & 0.686 & & \\
\hline Souvenirs sold here are unique and attractive. & & 0.705 & & \\
\hline There are sufficient sanitary toilets. & & 0.728 & & \\
\hline There are sufficient trash bins emptied in time. & & 0.720 & & \\
\hline This place provides a good service of telecommunication and network. & & 0.668 & & \\
\hline Visitor centre is easy to find. & & 0.709 & & \\
\hline The signs for traffic and tour are noticeable. & & 0.701 & & \\
\hline Upon leaving this place, I feel I enjoyed the expected service. & & 0.726 & & \\
\hline I would evaluate the service here favorably. & & 0.610 & & \\
\hline Traffic accessibility & 0.864 & & 0.864 & 0.614 \\
\hline Traffic to this place is convenient. & & 0.703 & & \\
\hline This tourist attraction is close to other scenic spots. & & 0.747 & & \\
\hline Traffic in this place is convenient and there are sufficient parking lots. & & 0.701 & & \\
\hline The roads in this place are broad and even. & & 0.732 & & \\
\hline
\end{tabular}

Table 3. Goodness of fit test of service quality measurement model.

\begin{tabular}{ccc}
\hline Fit Indices & Criteria & Results \\
\hline CMIN & & 1233.175 \\
DF & $<3$ & 460 \\
CMIN/DF & $>0.9$ & 2.681 \\
GFI & $>0.9$ & 0.952 \\
AGFI & $<0.08$ & 0.945 \\
RMSEA & $>0.9$ & 0.033 \\
IFI & $>0.9$ & 0.977 \\
NFI & $>0.9$ & 0.964 \\
TLI (NNFI) & $>0.9$ & 0.975 \\
CFI & & 0.977 \\
\hline
\end{tabular}

Confirmatory factor analysis of the service quality scale also showed that the CRs of employee-customer interaction, ambient condition, outcome and traffic accessibility were $0.908,0.945,0.938$ and 0.864 , respectively, all above the threshold value of 0.7 . Furthermore, the AVEs of the above four dimensions were $0.622,0.656,0.540$ and 0.614 respectively, all exceeding 0.5 . The data of CR and the AVE of service quality scale demonstrate that the service quality measurement model is acceptable. 


\subsection{Data Analysis of Place Attachment Scale}

Reliability and validity of place attachment scale were tested by using SPSS 24.0. Test results demonstrated that the value of Cronbach's alpha (within the range of 0.761 and 0.897 ) was above 0.7 , showing a good internal consistency of place attachment scale. Further exploratory analysis was carried out and factor loadings (between 0.701 and 0.838) of place attachment items were obtained, all above 0.5 , indicating the construct validity of place attachment scale is ideal. Composite reliability (CR) (within the range from 0.761 to 0.897 ) exceeded 0.60 , indicating a good reliability of the scale. (Table 4 ).

Table 4. Cronbach's alpha, factor loadings, CR and AVE of place attachment scale.

\begin{tabular}{|c|c|c|c|c|}
\hline Measured Variables and Dimensions & Cronbach's Alpha & Factor Loadings & CR & AVE \\
\hline Place dependence & 0.895 & & 0.897 & 0.635 \\
\hline \multirow{5}{*}{$\begin{array}{c}\text { This place is the best one for me to satisfy my travel needs. } \\
\text { Any other place cannot replace this tourist attraction to satisfy my } \\
\text { travel need. } \\
\text { I like this place better compared with other places. } \\
\text { No other place is better than this place. } \\
\text { I'm more satisfied when visiting this place than visiting any } \\
\text { other place. }\end{array}$} & & 0.777 & & \\
\hline & & 0.793 & & \\
\hline & & 0.802 & & \\
\hline & & 0.731 & & \\
\hline & & 0.792 & & \\
\hline Place identity & 0.845 & & 0.846 & 0.579 \\
\hline I have a strong identification with this place. & & 0.701 & & \\
\hline I'm attached to this place very much. & & 0.787 & & \\
\hline It is of great significance for me to visit this place. & & 0.805 & & \\
\hline Visiting this tourist attraction is part of my life. & & 0.767 & & \\
\hline Social bond & 0.861 & & 0.863 & 0.613 \\
\hline The staff here contributes to my pleasant travel experience. & & 0.737 & & \\
\hline Being on good terms with the staff here is important to me. & & 0.817 & & \\
\hline The staff here are very kind. & & 0.806 & & \\
\hline $\begin{array}{l}\text { The relationship established between me and others in this place is } \\
\text { very important to me. }\end{array}$ & & 0.718 & & \\
\hline Affective bond & 0.762 & & 0.761 & 0.614 \\
\hline Visiting this place makes me feel happy. & - & 0.838 & & \\
\hline Visiting this place excites me. & - & 0.829 & & \\
\hline
\end{tabular}

The convergent validity of the place attachment scale was tested through confirmatory factor analysis. The test results demonstrated that all indices were acceptable: CMIN/DF was 2.970, lower than 3, indicating the goodness of fit of the model. Other goodness of fit indicators including GFI (0.978), NFI (0.979), AGFI (0.970), TLI (0.983), CFI (0.986), IFI (0.986) were all above the threshold value of 0.9 and RMSEA was 0.036 , below 0.08 , which indicates that the model fitness is accepted (Table 5).

Table 5. Goodness of fit test of place attachment measurement model.

\begin{tabular}{ccc}
\hline Fit Indices & Criteria & Results \\
\hline CMIN & & 255.420 \\
DF & $<3$ & 86 \\
CMIN/DF & $>0.9$ & 2.970 \\
GFI & $>0.9$ & 0.978 \\
AGFI & $<0.08$ & 0.970 \\
RMSEA & $>0.9$ & 0.036 \\
IFI & $>0.9$ & 0.986 \\
NFI & $>0.9$ & 0.979 \\
TLI (NNFI) & $>0.9$ & 0.983 \\
CFI & & 0.986 \\
\hline
\end{tabular}

The confirmatory factor analysis of the place attachment scale also showed that the CRs of place independence, place identity, social bond and affective bond were $0.897,0.846$, 
0.863 and 0.761 , respectively, all above the threshold value of 0.7. Besides which, the AVEs of the above four dimensions were $0.635,0.579,0.613$ and 0.614 , respectively, all above 0.5 . The values of the CR and the AVE of place attachment scale demonstrate that the proposed model of place attachment is acceptable.

\subsection{Data Analysis of the Scale of the Environmentally Responsible Behaviour}

Reliability and validity of environmentally responsible behaviour scale are tested by using SPSS 24.0. The results show that the value of Cronbach's alpha is above than 0.7, which demonstrates that internal consistency of environmentally responsible behaviour scale is good. Further exploratory analysis is conducted by using principal component analysis and varimax rotation for factor analysis and convergent factors extraction. Factor loadings (within the range of 0.850 and 0.870 ) of environmentally responsible behaviour statements are significant. Composite reliability (CR) exceeds 0.60 , indicating a good reliability of the environmentally responsible behaviour scale. (Table 6).

Table 6. Cronbach's alpha, factor loadings, CR and AVE of environmentally responsible behaviour scale.

\begin{tabular}{|c|c|c|c|c|}
\hline Measured Variables and Dimensions & Cronbach's Alpha & Factor Loadings & CR & AVE \\
\hline On-site behaviour & 0.914 & & 0.914 & 0.728 \\
\hline $\begin{array}{c}\text { Seeing others' inappropriate environmental behaviour in this place, I will stop } \\
\text { it or report it to the management. }\end{array}$ & & 0.864 & & \\
\hline I don't litter while touring this place. & & 0.870 & & \\
\hline I try to protect the environment here while visiting this place. & & 0.856 & & \\
\hline I obey the environmental protection rules here. & & 0.860 & & \\
\hline Off-site behaviour & 0.912 & & 0.913 & 0.723 \\
\hline \multirow{4}{*}{$\begin{array}{l}\text { I try to get involved in solving the environmental problems in this place. } \\
\text { I would discuss with others about the environmental protection of this place. } \\
\text { I read books, ads and reports about the environmental protection of this place. } \\
\text { When I see someone damage the environment, I will persuade them to stop the } \\
\text { negative behaviours. }\end{array}$} & & 0.869 & & \\
\hline & & 0.850 & & \\
\hline & & 0.859 & & \\
\hline & & 0.862 & & \\
\hline
\end{tabular}

The convergent validity of the environmentally responsible behaviour scale is tested through confirmatory factor analysis. Test results show that all the indices were acceptable: CMIN/DF was 2.192, lower than 3, indicating that the fitting goodness of the model was good. Other goodness of fit indicators including GFI (0.993), NFI (0.995), AGFI (0.987), TLI (0.996), CFI (0.997), IFI (0.997) were all above the threshold value of 0.9 and the RMSEA was 0.028 , below 0.08 , which proves that the model fitness is accepted (Table 7).

Table 7. Goodness of Fit test of environmentally responsible behaviour measurement model.

\begin{tabular}{ccc}
\hline Fit Indices & Criteria & Test Results \\
\hline CMIN & & 41.649 \\
DF & $<3$ & 19 \\
CMIN/DF & $>0.9$ & 2.192 \\
GFI & $>0.9$ & 0.993 \\
AGFI & $<0.08$ & 0.987 \\
RMSEA & $>0.9$ & 0.028 \\
IFI & $>0.9$ & 0.997 \\
NFI & $>0.9$ & 0.995 \\
TLI (NNFI) & $>0.9$ & 0.996 \\
CFI & & 0.997 \\
\hline
\end{tabular}

The confirmatory factor analysis of the environmentally responsible behaviour scale also showed that the CRs of on-site behaviour and off-site behaviour were 0.914 and 0.913 , respectively, both above the threshold value of 0.7 . Besides which, the AVEs of the above two dimensions were 0.728 , and 0.723 , respectively, both above 0.5 . The statistics of the 
CR and the AVE of the environmentally responsible behaviour scale demonstrate that the proposed model of environmentally responsible behaviour is acceptable.

Average variance extracted (AVE) was employed to assess the validity of the scales of service quality, place attachment and environmentally responsible behaviour. The analysis results shown in Tables 2, 4 and 6 indicate that the AVEs of all the dimensions were above 0.5 and an AVE exceeding 0.5 represents a good convergent validity. If the square root of the AVE is higher than the correlation coefficient of the other variables, the discriminant validity is good. The following table shows that the square roots of the AVEs ranged from 0.735 to 0.853 , higher than the corresponding correlation coefficient, indicating a good discriminant validity (Table 8 ).

Table 8. Correlation matrix of the latent variables.

\begin{tabular}{|c|c|c|c|c|c|c|c|c|c|c|}
\hline Dimensions of Variables & 1 & 2 & 3 & 4 & 5 & 6 & 7 & 8 & 9 & 10 \\
\hline 1. Employee-customer interaction & $(0.784) \mathrm{a}$ & & & & & & & & & \\
\hline 2. Ambient condition & $(0.584) \mathrm{b}$ & 0.789 & & & & & & & & \\
\hline 3. Outcome & 0.477 & 0.626 & 0.810 & & & & & & & \\
\hline 4. Traffic accessibility & 0.385 & 0.571 & 0.672 & 0.735 & & & & & & \\
\hline 5. Place dependence & $0.384 * *$ & $0.419 * *$ & $0.444^{* *}$ & $0.433 * *$ & 0.797 & & & & & \\
\hline 6. Place identity & $0.322 * *$ & $0.419 * *$ & $0.418^{* *}$ & $0.374^{* *}$ & $0.517^{* *}$ & 0.761 & & & & \\
\hline 7. Social bond & $0.316^{* *}$ & $0.414^{* *}$ & $0.418^{* *}$ & $0.360 * *$ & $0.586^{* *}$ & $0.516^{* *}$ & 0.783 & & & \\
\hline 8. Affective bond & $0.209^{* *}$ & $0.303^{* *}$ & $0.274^{* *}$ & $0.277^{* *}$ & $0.424 * *$ & $0.483^{* *}$ & $0.433 * *$ & 0.784 & & \\
\hline 9. On-site behaviour & $0.333^{* *}$ & $0.397 * *$ & $0.377^{* *}$ & $0.369 * *$ & $0.380^{* *}$ & $0.339 * *$ & $0.347^{* *}$ & $0.279 * *$ & 0.853 & \\
\hline 10. Off-site behaviour & $0.372 * *$ & $0.449 * *$ & $0.481 * *$ & $0.479 * *$ & $0.409^{* *}$ & $0.408^{* *}$ & $0.389 * *$ & $0.293^{* *}$ & $0.496^{* *}$ & 0.850 \\
\hline
\end{tabular}

Note: "a" represents "diagonal values"; " $b$ " indicates "off-diagonal values". ${ }^{* *} p<0.01$.

\subsection{The Testing Results of the Three Hypotheses}

The goodness of fit test of the structural model indicated that all the indices were satisfactory (GFI $=0.939 ; \mathrm{AGFI}=0.934 ; \mathrm{NFI}=0.953 ; \mathrm{TLI}=0.975 ; \mathrm{IFI}=0.977 ; \mathrm{CFI}=0.977$ ). GFI, AGFI, NFI, TLI, IFI and CFI were between 0.90 and 1.00 and RMSEA was 0.024 , lower than 0.08 . The above analysis results demonstrate a good model fitness (Table 9).

Table 9. Goodness of fit indices for the structural model.

\begin{tabular}{ccc}
\hline Fit Indices & Criteria & Test Results \\
\hline CMIN & & 2742.463 \\
DF & & 1417 \\
CMIN/DF & $<3$ & 1.935 \\
GFI & $>0.9$ & 0.939 \\
AGFI & $>0.9$ & 0.934 \\
RMSEA & $<0.08$ & 0.024 \\
IFI & $>0.9$ & 0.977 \\
NFI & $>0.9$ & 0.953 \\
TLI (NNFI) & $>0.9$ & 0.975 \\
CFI & $>0.9$ & 0.977 \\
\hline
\end{tabular}

The relationships between service quality, place attachment and environmentally responsible behaviour hypothesised in the proposed model were tested by using AMOS 24 . The empirical results are exhibited in Table 10 and Figure 4.

Table 10. Summarised results of hypothesis testing.

\begin{tabular}{ccc}
\hline Proposed Hypotheses & Relationship between Variables & Results \\
\hline H1 & Service quality $\rightarrow$ Environmentally responsible behaviour & $0.515^{* * *}$ \\
H2 & Service quality $\rightarrow$ Place attachment & $0.701^{* * *}$ \\
H3 & Place attachment $\rightarrow$ Environmentally responsible behaviour & $0.357^{* * *}$ \\
\hline Note: ${ }^{* * *} p<0.001$. &
\end{tabular}




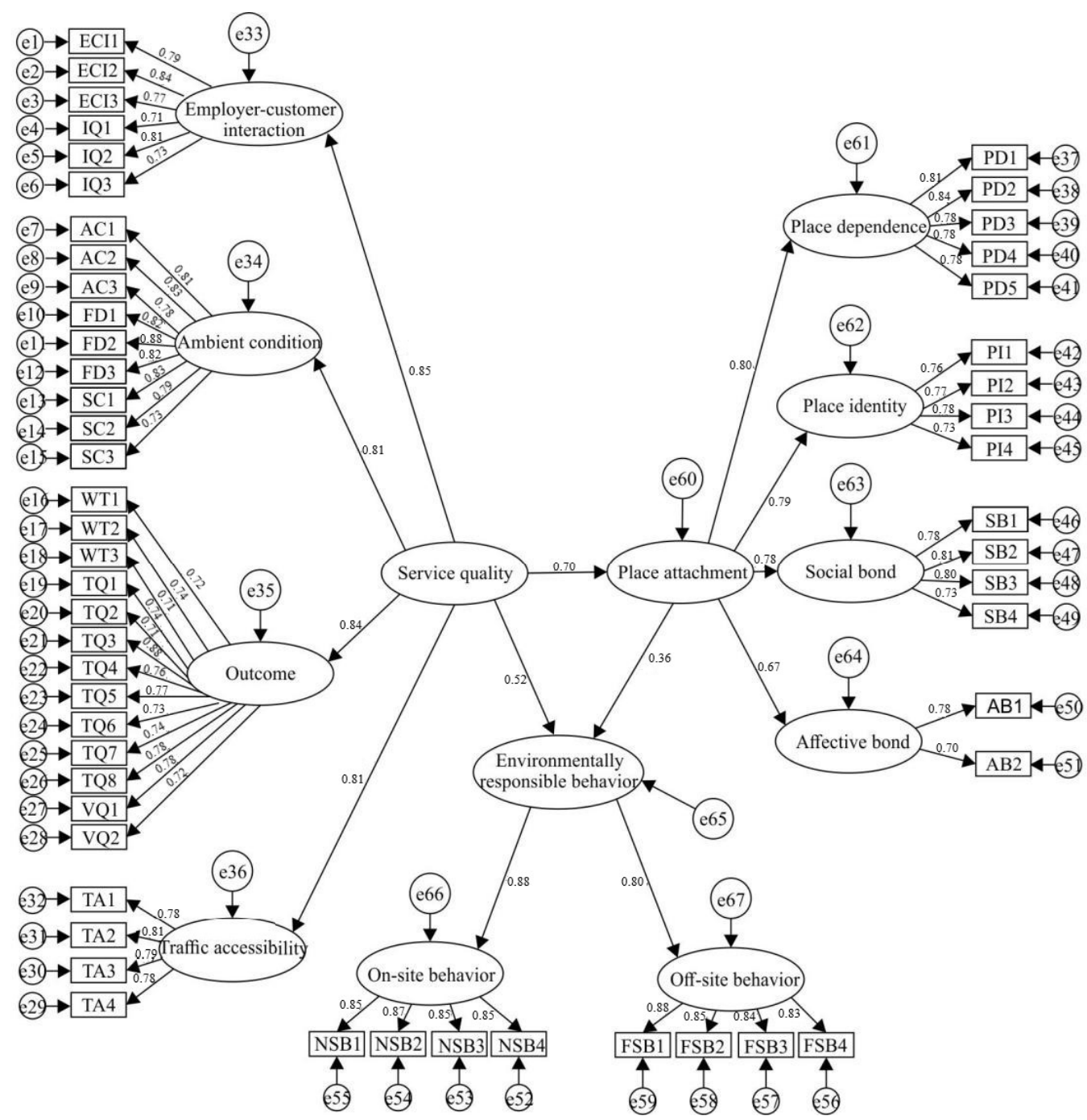

Figure 4. The structural model of the latent variables.

The test results indicate that hypothesis $\mathrm{H} 1$ with a path coefficient of 0.515 is supported, which means that service quality exerts a significantly positive influence on environmentally responsible behaviour. Besides which, hypothesis $\mathrm{H} 2$ is also accepted, with a path coefficient of 0.701 , namely service quality influences place attachment in a significantly positive manner. Meanwhile, $\mathrm{H} 3$ is supported with a path coefficient of 0.357 , showing that place attachment affects environmentally responsible behaviour in a positive way (Figure 4 and Table 10).

\subsection{The Testing Results of Hypothesis H4}

To test the degree to which place attachment contributes to the indirect relationship between service quality and environmentally responsible behaviour, a bootstrapping method was employed. As shown in Table 11, at 95\% confidence level, the confidence intervals of the bias-corrected method and the percentile method were $(0.196,0.309)$ and $(0.196$, 0.308 ) respectively, which do not contain zero, indicating the existence of a significantly indirect effect of place attachment. The bootstrapping testing results demonstrate that the link between service quality and tourists' environmentally responsible behaviour is mediated by place attachment. Table 10 shows that the direct effect of service quality on environmentally responsible behaviour was 0.515 and Table 11 shows that the indirect effect was 0.250 , hence the total effect of 0.765 . Namely, the mediation effect of place attachment is statistically significant, which mediates $32.6 \%(0.250 / 0.765)$ of the total effect of service quality on environmentally responsible behaviour. Therefore, hypothesis $\mathrm{H} 4$ is 
supported, suggesting that place attachment partially mediates the effect of service quality on tourists' environmentally responsible behaviour.

Table 11. Test result of mediating effect of place attachment.

\begin{tabular}{|c|c|c|c|c|c|}
\hline \multirow{3}{*}{ Path Coefficient } & \multirow{3}{*}{$\begin{array}{l}\text { Mediating Effect } \\
\text { Testing Results }\end{array}$} & \multirow{2}{*}{\multicolumn{2}{|c|}{$\begin{array}{c}\text { Bias-Corrected } \\
95 \% \text { CI }\end{array}$}} & \multirow{2}{*}{\multicolumn{2}{|c|}{$\begin{array}{c}\text { Percentile } \\
95 \% \text { CI }\end{array}$}} \\
\hline & & & & & \\
\hline & & Lower & Upper & Lower & Upper \\
\hline $\begin{array}{l}\text { service quality } \rightarrow \text { place attachment } \rightarrow \\
\text { environmentally responsible behaviour }\end{array}$ & 0.250 & 0.196 & 0.309 & 0.196 & 0.308 \\
\hline
\end{tabular}

Note: $95 \%$ CI refers to the confidence interval (CI): that is to estimate the range of overall parameters according to a certain probability.

The test results in Figure 4, Tables 9-11 showed that the theoretical model of the relationships between service quality, place attachment and environmentally responsible behaviour had a good degree of fit with the data collected from the respondents in the study areas, which is an acceptable model. The path analysis results indicated that service quality impacted on environmentally responsible behaviour in a significantly positive manner, with a path coefficient of $0.515(\mathrm{P}<0.001)$, proving that the hypothesis path $\mathrm{H} 1$ is tenable. What is more, service quality had a significantly positive influence on place attachment, with a path coefficient of $0.701(\mathrm{P}<0.001)$, assuming that path $\mathrm{H} 2$ is established. The path coefficient of the direct impact of place attachment on environmentally responsible behaviour was $0.357(\mathrm{P}<0.001)$, indicating that place attachment had a significantly positive impact on environmentally responsible behaviour, showing that the hypothesis path H3 holds. It was also found that service quality indirectly influenced environmentally responsible behaviour through place attachment, with a path coefficient of $0.250(\mathrm{P}<0.001)$, assuming that path $\mathrm{H} 4$ is established. The four hypothesised paths are thus verified, and their correlation is positive, showing a significant level. Therefore, the hypothetical relationships between service quality, place attachment and environmentally responsible behaviour are confirmed.

\section{Conclusions and Management Suggestions}

\subsection{Discussion}

Using both cultural heritage sites and nature-based site as study settings, this study has explored the relationships between service quality, place attachment and environmentally responsible behaviour to examine the antecedents of environmentally responsible behaviour. The analysis results are described as follows: first, service quality impacts environmentally responsible behaviour in a significantly positive manner, indicating that service quality is an antecedent variable and can be used to effectively predict environmentally responsible behaviour in tourists visiting cultural heritage sites and nature-based sites. Higher service quality will be conducive to encouraging tourists to exhibit environmentally responsible behaviour. This result is consistent with the results found in the only previous study by Kim et al. [24] which investigates the effect of festival quality on behavioural intention in a festival setting. Kim et al. in their research studied behavioural intentions in a rather broader sense because the behavioural intentions investigated include revisit, spread by word of mouth (WOM) and proenvironmental behaviour instead of focusing on one behavioural intention, namely environmentally responsible behaviour.

Second, the relationships examined by this study show that service quality influences place attachment in a positive manner, indicating that as service quality improves, the likelihood of place attachment also develops. This finding is in agreement with the results of past research conducted by Lee, Alexandris and Kim et al., but it conflicts with the study results found by Hwang et.al, which demonstrated that place attachment had a positive effect on interpretive service. This finding is also inconsistent with the conclusions reached in Morgan's research, which attempted to assess the effect of an interpretation service on place attachment, but the results showed that the place attachment scores were similar 
before and after the tour, indicating the former did not affect the latter. The researchers used different settings to examine the effect of service quality on place attachment or the other way round and different findings have been found, which demonstrates that the relationship between the two is not well established, hence the need for further exploration.

Third, this study has found that place attachment exerts a positive effect on environmentally responsible behaviour, indicating that the more tourists are attached to the tourist attraction, the more likely it is that they will display environmentally responsible behaviour. This finding concurs with the findings of past research [10,14] and proves that place attachment can be used to predict EAB.

Finally, the test results demonstrated that place attachment plays a significant role in affecting how service quality influences environmentally responsible behaviour, showing the significant moderating role of place attachment. This is the first time the mediating role of place attachment in impacting the influence of service quality on environmentally responsible behaviour has been explored. Such findings are consistent with the findings of the limited past studies [24,37]. Since the moderating role of place attachment has not gained much attention of scholars in the tourism field [38], it is worthwhile continuing to conduct the relevant research.

\subsection{Conclusions}

Very few studies have investigated how service quality impacts environmentally responsible behaviour and place attachment, respectively. This study has examined the antecedents of environmentally responsible behaviour at cultural heritage sites and a nature-based site in Shaanxi, China, by creating a theoretical model representing the relationships between service quality, place attachment and environmentally responsible behaviour, which is the first time in tourism literature that the structural relationships between the three variables in the same model have been simultaneously examined. The test results of the structural equation model in the current study suggest that service quality has a significantly positive effect on environmentally responsible behaviour and place attachment. Additionally, place attachment exerts significantly positive influence on environmentally responsible behaviour. Moreover, place attachment partially mediates the relationship between service quality and environmentally responsible behaviour. On the one hand, the study contributes to tourism literature in that it helps researchers better understand the influencing factors of environmentally responsible behaviour at tourist attractions and might also stir other researchers' interest in further exploring the effect of service quality on environmentally responsible behaviour in other settings. On the other hand, it also provides valuable evidence for the management of tourist attractions that improvements in service quality at cultural heritage sites and nature-based sites may help encourage visitors to exhibit environmentally responsible behaviour, which will contribute to the sustainable use of tourism resources and the sustainable development of local tourism.

\subsection{Management Suggestions}

The income from cultural heritage-based tourism and nature-based tourism in Shaanxi of CNY 481.3 billion (USD 74.5 billion) in 2017 constituted a considerable portion of the revenues of the local government. It is of great significance for local government to maintain the sustainable use of tourism resources and sustainable development of tourism. Since visitors' environmentally responsible behaviour is conducive to tourism development, the management of tourist attractions should value tourists' behaviours. According to the proposed model in the present study, environmentally responsible behaviour is significantly influenced by service quality and place attachment. Therefore, tourism management should strive to improve service quality to help visitors to develop place attachment and display environmentally responsible behaviour.

The evaluation of service quality in this study shows that service quality is not satisfactory. It is suggested that the management of tourist attractions should improve service 
quality from the following aspects. First, the management may improve the quality of employee-customer interaction by organizing regular training programs to familiarize service personnel with service knowledge and skills to better serve tourists. Second, special service personnel should be organised to persuade tourists to behave politely, especially to stop them from littering and spitting. Third, traffic and parking conditions should be improved by providing rental bicycles along some busy routes and building more parking lots on the site.

Since place attachment also impacts environmentally responsible behaviour in a significantly positive manner, the management of the tourist attraction also needs to help develop the tourists' emotional attachment to the visited site from the following aspects. Place dependence stresses an individual's functional dependence on a place, especially the attributes of the place which may satisfy consumers' purposes or expectations. It was found in the study that traffic accessibility affected visitors' place dependence. The local government could improve traffic conditions in and around the scenic spot by broadening the road, adding new transportation routes, developing three-dimensional transportation, and paying attention to the dynamic update of transportation tools to make the surrounding transportation network modern and convenient. This will help tourists to develop place dependence on the visited site.

Place identity emphasizes the symbolic meaning of a place to individuals and represents the individuals' emotional attachment to the place. To promote the generation of the tourists' place identity, the management of tourist attractions can provide tourists with personalised services, and respond to the needs of tourists in a meticulous, timely and effective manner. Through the establishment of high-quality service and service relationships with tourists, tourists can feel emotionally harmonious, intimate and comfortable.

Some researchers believe that an individual's attachment to a place is not only an attachment to the place itself, but also to the social relationships that exist in this place. As far as the social relationship in the scenic spot is concerned, it mainly refers to the social relationship that may be established between the tourist and the service. Therefore, the management may enhance the social connection of tourists by providing some entertainment projects that tourists can participate in on-site so as to establish a harmonious relationship between the two.

In short, the management of tourist attractions should take the above actions to improve service quality and promote the place attachment of visitors to encourage visitors' to display environmentally responsible behaviour in order to achieve the sustainable use of tourism resources and sustainable development of local tourism in the long run.

\subsection{Limitations and Future Research}

Although this study contributes to research on examining antecedents of environmentally responsible behaviour in the tourism field, the findings need to be qualified by the following limitations. First, the scale devised to assess environmentally responsible behaviour only focuses on the behavioural intention of the visitors instead of their actual behaviour. Investigating visitors' actual behaviour is rather difficult since it will take a longer time and more money. If possible, future research may attempt to evaluate the actual on-site behaviour by videotaping the visitors with their permission and track their off-site behaviour via email reports. Second, the data collected for this study were obtained by distributing questionnaires to tourists at the exit of each visited site after they finish their visit. Some of them were either tired or in a hurry to leave, which resulted in their impatience with assessing all the items of the questionnaires, leading to some less actual assessments. The future research might avoid such a limitation by combining a questionnaire survey with an in-depth interview to obtain more convincing data. Third, a limitation exists in sampling since the surveys were conducted mainly on weekends and holidays, especially in peak season. Future research may extend the time duration for questionnaire surveys to include respondents in both peak season and off-season to guarantee the diversity of the sample. 
Author Contributions: Conceptualization, T.E.C. and M.C.; Data curation, H.Z.; Formal analysis, H.Z.; Investigation, S.L. and H.Z.; Methodology, T.E.C.; Software, H.Z.; Supervision, M.C.; Validation, M.C.; Writing—original draft, T.E.C.; Writing—review \& editing, T.E.C. and M.C. All authors have read and agreed to the published version of the manuscript.

Funding: This research was funded by the following agencies: Shaanxi Social Science Academy (grant number: 2017S006); Xi'an Social Science Academy (grant number: 2020WL185); Human Resource Department, Northwest University (2019-2021). The APC was funded by Shaanxi Social Science Academy (grant number: 2017S006).

Institutional Review Board Statement: Ethical review and approval were waived for this research since all the subjects were over the age of 18 .

Informed Consent Statement: Informed consent was obtained from all the respondents involved in the study.

Data Availability Statement: The data will be made available on request by contacting Tian E Cheng via cte201707@nwu.edu.cn.

Conflicts of Interest: The authors declare no conflict of interest.

\section{Appendix A}

\section{VISITOR SURVEY}

In this survey, we'd like to ask you to evaluate the service quality of the tourist attraction you visited today, your attachment to it and your behaviours exhibited on and off the site. Your evaluation will help us make some significant management suggestions about the service quality of the visited place. The survey is voluntary and anonymous. Your honest, personal opinions are greatly appreciated. It takes you around 10 minutes to complete it. Thanks for your time!

\section{Northwest University}

\section{Your evaluations of the service quality}

How would you evaluate the service quality of the visited place?

\begin{tabular}{|l|}
\hline \multicolumn{1}{|c|}{ Statements } \\
\hline 1. The staff here are friendly and well-mannered. \\
\hline 2. The staff here serve visitors actively. \\
\hline 3. The staff are experienced in solving visitors' problems. \\
\hline 4. Tour guides have considerable expertise in this tourist attraction. \\
\hline 5. Tour guides are competent in their job. \\
\hline 6. Tour guides can give timely and accurate answers to visitors' questions. \\
\hline 7. This place is peaceful and attractive. \\
\hline 8. The climate here is comfortable and pleasant. \\
\hline 9. It is safe to tour this place. \\
\hline 10. Tour routes are well designed. \\
\hline 11. The style and colour of the buildings and other facilities on the site match the surroundings. \\
\hline 12. The layout of the facilities is reasonable. \\
\hline 13. Visitors here are polite and well mannered. \\
\hline 14. The number of visitors influences service quality of the site. \\
\hline 15. The management of this place is aware that the number of visitors influences service quality. \\
\hline 16. The staff serve tourists promptly. \\
\hline 17. The management tries to reduce visitors' waiting time for service. \\
\hline
\end{tabular}




\begin{tabular}{|l|}
\hline \multicolumn{1}{|c|}{ Statements } \\
\hline 18. Waiting time in this place can be predicted. \\
\hline 19. Sufficient quality recreational facilities are provided for visitors. \\
\hline 20. Restaurants here are sanitary. \\
\hline 21. Souvenirs sold here are unique and attractive. \\
\hline 22. There are sufficient sanitary toilets. \\
\hline 23. There are sufficient trash bins emptied frequently. \\
\hline 24. This place provides a good service of telecommunication and network. \\
\hline 25. Visitor centre is easy to find. \\
\hline 26. The signs for traffic and tour are easily visible. \\
\hline 27. Upon leaving this place, I feel I enjoyed the expected service. \\
\hline 28. I would evaluate the service here favourably. \\
\hline 29. Traffic to this place is convenient. \\
\hline 30. This tourist attraction is close to other scenic spots. \\
\hline 31. Traffic in this place is convenient and there are sufficient parking lots. \\
\hline 32. The roads in this place are broad and even. \\
\hline
\end{tabular}

\section{Your attachment to the visited site}

How much are you emotionally attached to this tourist attraction?

\begin{tabular}{|l|}
\hline \multicolumn{1}{|c|}{ Statements } \\
\hline 33. This place is the best one for me to satisfy my travel needs. \\
\hline 34. No other place can replace this tourist attraction to satisfy my travel needs. \\
\hline 35. I like this place better compared with other places. \\
\hline 36. No other place is better than this place. \\
\hline 37. I get more satisfaction out of visiting this place than I do in any other place. \\
\hline 38. I identify strongly with this visited site. \\
\hline 39. I am attached to this visited site a lot. \\
\hline 40. It is of great significance for me to visit this place. \\
\hline 41. Visiting this tourist attraction is part of my life. \\
\hline 42. The staff here contributes to my pleasant travel experience. \\
\hline 43. Being on good terms with the staff here is important for me. \\
\hline 44. The staff here are very kind. \\
\hline 45. The relationship established between me and others in this place is very important for me. \\
\hline 46. Visiting this place makes me feel happy. \\
\hline 47. Visiting this place excites me. \\
\hline
\end{tabular}

\section{Your behaviours exhibited on and off the visited site}

What were or would be your behaviours exhibited on and off the visited site?

\begin{tabular}{|l|}
\hline \multicolumn{1}{|c|}{ Statements } \\
\hline $\begin{array}{l}\text { 48. Seeing others' inappropriate environmental behaviour in this place, I would stop it or report it to the } \\
\text { management. }\end{array}$ \\
\hline 49. I don't litter while touring this place. \\
\hline 50. I try to protect the environment here while visiting this place. \\
\hline 51. I obey the environmental protection rules here. \\
\hline 52. I try to get involved in solving the environmental problems in this place. \\
\hline 53. I would discuss with others about the environmental protection of this place. \\
\hline 54. I read books, ads and reports about environmental protection of this place. \\
\hline 55. When I see someone damaging the environment, I will persuade them to stop the negative behaviours. \\
\hline
\end{tabular}




\section{Demographic traits}

Your gender: $\square$ male $\square$ female Your age: $\square$ 18-24 $\square$ 25-34 $\square$ 35-44 $\square$ 45-54 $\square$ 55-64 $\square \geq 65$

Marital status: $\square$ unmarried $\square$ married

Your education: $\square$ junior high school $\square$ senior high school $\square$ university or college $\square$ postgraduate

Your companion: $\square$ with tour group $\square$ alone $\square$ with friends

$\square$ with families $\square$ with others

You are from: $\square$ European countries $\square$ American countries $\square$ the UK

$\square$ Asian countries $\square$ other countries

Previous visits: $\square$ first time $\square$ two times $\square$ three times or more

How many hours did you spend visiting this place?

$\square$ 1-2 hours $\square$ 3-4 hours $\square$ more than 4 hours

Your motivation for visiting this place: (you may choose more than one answer)

$\square$ to learn about knowledge of local history and culture $\square$ seeking a nostalgic experience

$\square$ broaden horizons $\square$ to relax and relieve pressure

$\square$ due to the reputation of this place $\square$ to accompany others $\square$ other reason

\section{THANKS FOR YOUR COOPERATION!}

\section{References}

1. Lee, T.H.; Jan, F.H.; Yang, C.C. Conceptualizing and measuring environmentally responsible behaviors from the perspective of community-based tourists. Tour. Manag. 2013, 36, 454-468. [CrossRef]

2. Ballantyne, B.; Packer, J.; Hughes, K. Tourists' support for conservation messages and sustainable management practices in wildlife tourism experiences. Tour. Manag. 2009, 30, 658-664. [CrossRef]

3. Halpenny, E.A. Pro-environmental behaviours and park visitors: The effect of place attachment. J. Environ. Psychol. 2010, 30, 409-421. [CrossRef]

4. Williams, D.; Vaske, J. The measurement of place attachment: Validity and generalizability of a psychometric approach. For. Sci. 2003, 49, 830-840.

5. Campelo, A.; Aitken, R.; Thyne, M.; Gnoth, J. Sense of place: The importance for destination branding. J. Travel Res. 2014, 53, 154-166. [CrossRef]

6. Bricker, K.S.; Kerstetter, D.L. Level of specialization and place attachment: An exploratory study of whitewater recreationists. Leis. Sci. 2000, 22, 233-257.

7. Lee, J.; Graefe, A.R.; Burns, R.C. Examining the antecedents of destination loyalty in a forest setting. Leis. Sci. 2007, 29, 463-481. [CrossRef]

8. Mechinda, P.; Serirat, S.; Gulid, N. An examination of tourists' attitudinal and behavioral loyalty: Comparison between domestic and international tourists. J. Vacat. Mark. 2009, 15, 129-148. [CrossRef]

9. Ramkissoon, H.; Smith, L.D.G.; Weiler, B. Relationships between place attachment, place satisfaction and pro-environmental behaviour in an Australian national park. J. Sustain. Tour. 2013, 21, 434-457. [CrossRef]

10. Tonge, J.; Ryan, M.M.S.; Moore, A.; Beckley, L.E. The effect of place attachment on pro-environment behavioral intentions of visitors to coastal natural area tourist destinations. J. Travel Res. 2015, 54, 1-14. [CrossRef]

11. Devine-Wright, P.; Howes, Y. Disruption to place attachment and the protection of restorative environments: A wind energy case study. J. Environ. Psychol. 2010, 30, 271-280. [CrossRef]

12. Gosling, E.; Williams, K. Connectedness to nature, place attachment and conservation behavior: Testing connectedness theory among farmers. J. Environ. Psychol. 2010, 30, 298-304. [CrossRef]

13. Lee, T.H. How recreation involvement, place attachment and conservation commitment affect environmentally responsible behavior. J. Sustain. Tour. 2011, 19, 895-915. [CrossRef]

14. Ramkissoon, H.; Smith, L.D.G.; Weiler, B. Testing the dimensionality of place attachment and its relationships with place satisfaction and pro-environmental behaviors: A structural equation modeling approach. Tour. Manag. 2013, 36, 552-566. [CrossRef]

15. Cronin, J.J.; Brady, M.K.; Hult, G.T.M. Assessing the effects of quality, value, and customer satisfaction on consumer behavioral intentions in service environments. J. Retail. 2000, 76, 193-218. [CrossRef]

16. Bloemer, J.; Ruyter, K. On the relationship between store image, store satisfaction and store loyalty. Eur. J. Mark. 1998, 32, 499-513. [CrossRef]

17. Theodorakis, N.D.; Tsigilis, N.; Alexandris, K. The mediating role of place attachment on the relationship between service quality and loyalty in the context of skiing. Int. J. Sport Manag. Mark. 2009, 6, 277-291. [CrossRef] 
18. Saha, G.C. Service quality, satisfaction, and behavioural intentions: A study of low-cost airline carriers in Thailand. Manag. Serv. Qual. Int. J. 2009, 19, 350-372. [CrossRef]

19. Lee, J.H.; Kim, H.D.; Sagas, M. The influence of service quality on satisfaction and intention: A gender segmentation strategy. Sport Manag. Rev. 2011, 14, 54-63. [CrossRef]

20. Allameh, S.M.; Pool, J.K.; Jaberi, A.; Salehzadeh, R.; Asadi, H. Factors influencing sport tourists' revisit intentions: The role and effect of destination image, perceived quality, perceived value and satisfaction. Asia Pac. J. Mark. Logist. 2015, 27, 191-207. [CrossRef]

21. Quintal, V.A.; Polczynski, A. Factors influencing tourists' revisit intentions. Asia Pac. J. Mark. Logist. 2010, 22, 554-578. [CrossRef]

22. Cong, L.C. A formative model of the relationship between destination quality, tourist satisfaction and intentional loyalty: An empirical test in Vietnam. J. Hosp. Tour. Manag. 2016, 26, 50-62. [CrossRef]

23. Wang, T.L.; Tran, P.T.K.; Tran, V.T. Destination perceived quality, tourist satisfaction and word-of-mouth. Tour. Rev. 2017, 72, 392-410. [CrossRef]

24. Kim, S.; Lee, Y.K.; Lee, C.K. The moderating effect of place attachment on the relationship between festival quality and behavioral intentions. Asia Pac. J. Mark. Logist. 2017, 22, 49-63. [CrossRef]

25. Lee, J. Examining the Antecedents of Loyalty in a Forest Setting: Relationships among Service Quality, Satisfaction, Activity Involvement, Place Attachment, and Destination Loyalty. Ph.D. Thesis, The Pennsylvania State University, State College, PA, USA, 2003.

26. Alexandris, K.; Kouthouris, C.; Melogdis, A. Increasing customers' loyalty in a skiing resort: The contribution of place attachment and service quality. Int. J. Contemp. Hosp. Manag. 2006, 18, 414-425. [CrossRef]

27. Hwang, S.N.; Lee, C.; Chen, H.J. The relationship among tourists' involvement, place attachment and interpretation satisfaction in Taiwan's national parks. Tour. Manag. 2005, 26, 143-156. [CrossRef]

28. Morgan, M. Interpretation and place attachment implications for cognitive map theory. J. Interpret. Res. 2009, 14, 47-59. [CrossRef]

29. Chiou, J.S.; Droge, C. Service quality, trust, specific asset investment and expertise: Direct versus indirect effects in a satisfaction and loyalty framework. J. Acad. Mark. Sci. 2006, 34, 1-15. [CrossRef]

30. Chen, C.F.; Tsai, D. How destination image and evaluative factors affect behavioral intentions? Tour. Manag. 2007, 28, 1115-1122 [CrossRef]

31. Clemes, D.M.; Gan, C.; Ren, M. Synthesizing the effects of service quality, value, and customer satisfaction on behavioral in-tentions in the motel industry: An empirical analysis. J. Hosp. Tour. Res. 2011, 35, 530-568. [CrossRef]

32. Lai, W.T.; Chen, C.F. Behavioral intentions of public transit passengers-The roles of service quality, perceived value, satis-faction and involvement. Transp. Policy 2011, 18, 318-325. [CrossRef]

33. Williams, D.R.; Roggenbuck, J.W. Measuring place attachment: Some preliminary results. In Proceedings of the NRPA Symposium on Leisure Research, San Antonio, TX, USA, 20-22 October 1989.

34. Cheng, T.M.; Wu, H.C.; Huang, L.M. The influence of place attachment on the relationship between destination attractiveness and environmentally responsible behavior for island tourism in Penghu, Taiwan. J. Sustain. Tour. 2013, 21, 1166-1187. [CrossRef]

35. Vaske, J.J.; Kobrin, K.C. Place attachment and environmentally responsible behavior. J. Environ. Educ. 2001, 32, 16-21. [CrossRef]

36. Smith-Sebasto, N.J.; D'costa, A. Designing a Likert-Type scale to predict environmentally responsible behavior in undergraduate students: A multistep process. J. Environ. Educ. 1995, 27, 14-20. [CrossRef]

37. Theodorakis, N.D.; Koustelios, A.; Robinson, L.; Barlas, A. Moderating role of team identification on the relationship between service quality and repurchase intentions among spectators of professional sports. Manag. Serv. Qual. 2009, 19, 456-472. [CrossRef]

38. Gross, M.J.; Brown, G. Tourism experiences in a lifestyle destination setting: The roles of involvement and place attachment. J. Bus. Res. 2006, 59, 696-700. [CrossRef] 